\title{
EFFECTS OF FISCAL POLICY SHOCKS IN CE3 COUNTRIES (TVAR APPROACH)
}

\author{
Rajmund Mirdala, Martin Kameník
}

\section{Introduction}

European Union member countries experienced a decrease in the macroeconomic performance during the early stages of the economic and debt crisis. Significant deterioration in the fiscal stance as one of the primary implications of the economic recession revealed questions associated with fiscal sustainability in terms of threshold levels of fiscal deficit and sovereign debt that individual countries can sustain over longer period of time (Wöhlbier, Astarita, \& Mourre, 2014). Fiscal implications of the economic crisis varied across European Union member countries considering existing differences in the financial discipline of fiscal authorities (levels of fiscal budget balance and sovereign debt), overall macroeconomic performance and high level of heterogeneity of individual markets that altogether affects the overall costs of fiscal consolidation (European Commission, 2012). On the other hand, both theoretical and empirical literature provides robust evidence on benefits of fiscal incentives based on adjustments on expenditure, revenue or both sides of the government budget that stimulates economies during the bad times (Corsetti, Kuester, Meier, \& Müller, 2010). However, structural patterns of crises related external shocks, large interconnection and interdependence among countries as well as oversized sovereign debt burden reduced maneuverability for fiscal stimuli and shrunk countercyclical framework for national fiscal policies (Ilzetzki, Mendoza, \& Végh, 2011; Farkašovský, Lawson, \& Zimková, 2015). As a result, disputable implications of fiscal incentives remained contrary to the crucial need of the effective fiscal consolidation that was necessary to reduce excessive fiscal deficits and high sovereign debts. Finally, governments focused on the reduction of public expenditures and increase in taxes during the periods of lagging recession and thus cooled down economies (Burnside, Eichenbaum, \& Fisher, 2003). However, an appropriate composition of fiscal incentives without direct negative effect on the public budget and its revenue and expenditure sides may help to reduce negative budgetary pressures through increased tax capacity of the economy followed by stronger growth of the real output.

The overall success of the large fiscal adjustments (following either the idea of fiscal consolidation or fiscal stimuli) may differ across individual countries (due to i.e. direct and spillover effects of quantitative easing, effects of internal and external (in countries outside the Euro Area) devaluation, reforms of fiscal institutions, etc.) (Barrios, Langedijk, \& Penc, 2010). Elimination of significant adjustments in the primary fiscal balance is the most convenient way to reduce a negative impact of fiscal policy on economic growth (Perotti, 2005). While significant improvements in the primary fiscal balance during the fiscal contraction (i.e. fiscal consolidation) may be followed by economic growth slowdown (Mountford \& Uhlig, 2008), significant deteriorations in the primary fiscal balance during the fiscal expansion (i.e. fiscal stimuli) increases sovereign debt burden that may induce a subsequent recession after reaching the threshold level (Cournède \& Gonand, 2006). Moreover, according to the empirical literature, effects of fiscal adjustments clearly differ in good times and bad times (Fernandez \& Hernandez de Cos, 2006; Heppke-Falk, Tenhofen, \& Wolff, 2006). As a result, the size of fiscal multipliers is changing in the different stages of the business cycle (Caggiano, Castelnuovo, Colombo, \& Nodari, 2015; Ramey \& Zubairy, 2014).

In the paper we examine effects of the fiscal policy shocks in CE3 (the Slovak Republic, the Czech Republic and Hungary) within 
different stages of the business cycle. The main objective is to determine whether effects of the fiscal policy shocks differ in "good" and "bad" economic times, i.e. during expansion and recession. Moreover, we calculate the size of fiscal multipliers at CE3 countries. The analyzed period starts at the peak of economic transition of those countries in 1995 and 1996 and ends in 2015. Our research idea is based on the assumption that key implications of fiscal adjustments are generally sensitive to the recent stage of the business cycle and thus affect the responsiveness of real output to the changes in government revenues and expenditures (Alesina \& Ardagna, 2009). We employ threshold VAR methodology pioneered by Tsay (1998). Before the estimation of nonlinear TVAR model, the non-linearity test has to be conducted in order to detect threshold nonlinearity in time series. While the parameters of each regime are estimated by simple OLS, the non-linearity results from the transitions between regimes and therefore traditional impulse response functions cannot be used to analyze effects of fiscal policy shocks. Instead, we use the concept of generalized impulse response functions (Koop et al., 1996). Moreover, we calculate fiscal multipliers and examine effects of economic crisis on their size. To provide more rigorous insight into the impact of crisis on effects of fiscal policy we evaluate the policy effects separately in pre-crisis and crisis period. We assume that a comparison of the results for different time period is essential to understand the changes of fiscal policy effects on economic activity.

While the effects of fiscal policy shocks in the new EU member countries is well documented in the recent empirical literature (i.e. Borys, Ciżkowicz and Rzońca (2013); Cauresma, Eller, and Mehrotra, (2011), Filipovski, Fiti, and Trenovski (2016); Boiciuc (2016); Dumitrescu (2015); Ćorić, Šimović, and Deskar-Škrbić (2015); Franta (2012); Petrevski, Bogoev, and Tevdovski (2015)), diversity in methodology, sample size as well as observed period results in mixed evidence about the size of fiscal multipliers, the real output responsiveness to the fiscal adjustments and, as a result, counter-cyclical and/or pro-cyclical patterns in the fiscal policy. Estimated threshold VAR model in our paper for CE3 countries revealed fundamentally new information about the effects of fiscal policy shocks. Our results indicate that the size of fiscal multipliers and responsiveness of the real output are generally higher for spending fiscal shocks while the effects of the revenue fiscal shocks are much less dynamic in all three countries. Moreover, while the effects of the fiscal spending shocks are more dynamic during recession in the Czech Republic and Hungary, fiscal spending multipliers in the Slovak Republic are generally high during the recession as well though higher during expansion. While the fiscal revenue shocks have generally negligible effect on the output over the increasing horizon in all three countries, the distribution of the size of fiscal revenue multipliers between both regimes is similar in all three countries (larger in the Czech Republic and Hungary during recession while larger in the Slovak Republic during expansion).

Following the introduction, we provide an overview of current empirical evidence about effects of fiscal policy shocks. Wide range of causal implications of spending and revenue based fiscal adjustments as well as their size and durability is well documented in papers published during the last two decades. Section 2 provides an overview of the threshold VAR methodology considering two regimes, identification of fiscal policy shocks and calculation of generalized impulse-response functions and fiscal multipliers. Analysis of effects of the fiscal policy shocks in CE3 countries (section 3 ) examines responsiveness of real output to the $1 \%$ and $5 \%$ spending and revenue based fiscal shocks. Finally, section 4 provides concluding remarks.

\section{Overview of Literature}

Effects of fiscal policy shocks are well documented especially on the sample of developed countries. Blanchard and Perotti (2002) employed mixed structural VAR/event study approach to identify the automatic responses of taxes and government spending to economic activity. They also argued that positive government spending shocks have a positive effect on output, while positive tax shocks have a negative effect on output. The multipliers for both spending and tax shocks are typically small.

Perotti (2005) implemented SVAR approach to analyze the effect of fiscal policy on output, prices and interest rates in five OECD countries. The results can be summarized as follows: 1) The effects of fiscal policy on output and its 
components have become substantially weaker in the last 20 years; 2) The tax multipliers tend to be negative but small; 3) Once plausible values of the price elasticity of governments spending are imposed, the negative effects of government spending on prices that have been frequently estimated become positive, although usually small and not always significant; 4) Government spending shocks have significant effects on the real short-term interest rate, but uncertain signs; 5) Net tax shocks have very small effects on prices; 6 ) The U.S. is an outlier in many dimensions; U.S. responses to fiscal shocks are often not representative of the average OECD country included in this sample.

Giuliodori and Beetsma (2004) also implemented few identifications schemes using VAR methodology to analyze the (spill-over) effects of fiscal policy shocks in European economies. Their analysis is focused on the indirect channel of transmitting the fiscal policy shocks that affect an import of the country. They also emphasized a necessity of enhanced fiscal coordination at the macroeconomic level.

Romer and Romer (2007) analyze the causes and consequences in the level of taxation in the postwar U.S. Their results indicate that tax changes have very large effects on output. At the same time output effects are very persistent. Authors argue it is due to the strong response of investments to the tax burden decrease.

Caldara and Camps (2008) provide empirical evidence on the response of key macroeconomic variables to government spending and tax revenue shocks for the U.S. over the period 19552006. Authors implemented four approaches (the recursive approach, the Blanchard-Perotti approach, the sign-restrictions approach and the event-study approach) to identify their system based on the VAR methodology. While there is the empirical evidence that the positive responses of private consumption and the real wage are very persistent, authors argued that the most current-generation DSGE models consistent with an increase in these variables predict that the responses turn negative already about one year after the government spending shock occurs. They also find strongly diverging results as regards the effects of tax shocks depending on the identification approach used, with the estimated effects of unanticipated tax increases ranging from non-distortionary to strongly distortionary.
Baum et al. (2012) examined effects of fiscal policy shocks on output in Germany within linear VAR and non-linear TVAR model. They showed that the state of the business cycle matters and that the fiscal multipliers are higher at the times of downturn than in expansion. The latter study builds on the first and estimate fiscal multipliers of $\mathrm{G} 7$ economies (excluding Italy). Presented results are qualitatively similar to previous study. Both works followed identification scheme proposed by Blanchard and Perotti (2002). Another closely related study based on TVAR approach where authors estimated the impact of fiscal policy is work of Batini et al. (2012) for the United States, Europe and Japan or Hernández de Cos et al. (2013) for Spain. Author showed that the resulted fiscal multipliers during the recession exceed fiscal multipliers in expansion. A slightly different approach used Ferraresi et al. (2014) who employed TVAR to assess how the fiscal policy effects differ depending on state of the credit markets. Or the work of Afonso et al. (2011), where authors investigated how the stress in financial markets affect fiscal policy in United States, United Kingdom, Germany and Italy. Benčík (2014) used modified version of Auerbach and Gorodnichenko (2012) smooth transition VAR model to calculate regime fiscal multipliers for recession and expansion in V4 countries.

\section{Threshold VAR Methodology}

VAR models represent dynamic systems of equations in which the current level of each variable depends on past movements of that variable and all other variables involved in the system. Residuals of vector $u_{t}$ represent unexplained movements in variables (effects of exogenous shocks hitting the model); however as complex functions of structural shocks effects they have no economic interpretation. Structural shocks can be still recovered using transformation of the true form representation into the reduced-form by imposing a number of identifying restrictions. Applied restrictions should reflect some general assumptions about the underlying structure of the economy and they are obviously derived from economic theory. There are two general (most used) approaches to identify VAR models. (I) Cholesky decomposition of innovations implies the contemporaneous interactions between exogenous shocks and the endogenous 
variables are characterized by a Wald causal chain. Ordering of endogenous variables then reflects expected particular economy structure following general economic theory assumptions. However, the lack of reasonable guidance for appropriate ordering led to the development of more sophisticated and flexible identification methods - (II) structural VAR (SVAR) models. Identifying restrictions implemented in SVAR models reflect theoretical assumptions about the economy structure more precisely.

Our paper is based on the work of Baum et al. (2011) and Baum et al. (2012). The former study examines the effects of fiscal policy shocks on output in Germany within linear VAR and non-linear TVAR (threshold vector autoregression) model. Two-regime TVAR model with threshold variable $z_{t}$ and delay $d$ can be defined as follows

$$
\begin{aligned}
& Y_{t}=D_{1}(L) Y_{t-1} I\left[z_{t-d} \leq z^{*}\right]+ \\
& +D_{2}(L) Y_{t-1} I\left[z_{t-d}>\mathrm{z}^{*}\right]+u_{t}
\end{aligned}
$$

where $Y_{t}=\left(T_{t}, G_{t}, G D P_{t}\right)^{T}$ is a vector of endogenous variables (government revenues, government spending and real output) and $u_{t}=\left(u_{t}^{T}, u_{t}^{G}, u_{t}^{G D P}\right)$ is the vector of reduced form residuals. Subsequently $I[$.] represents an indicator function that equals 1 if the condition holds and 0 otherwise. The threshold value $z^{*}$ together with the lag polynomial matrices $D_{1}(L)$ and $D_{2}(L)$ (including deterministic constant) have to be estimated.

Threshold variable $z_{t}$ determines the prevailing regime of the system where lag polynomial matrix can vary. We set the threshold delay parameter $d$ to 1 as is common in related studies - The prevailing regime is determined by the threshold variable in previous period. If the threshold variable $z$ at time $t-1$ exceeds the threshold value $z^{*}$ the variables are determined by parameters of upper regime and vice versa (Baum, 2011; Batini, 2012). TVAR model with two regimes appears to be the most appropriate option because it best fits the character of the business cycles - it clearly distinguishes between positive and negative output gap. Moreover the choice of only two regimes is suitable due to the low number of available observations.

Before we proceed to estimation of TVAR model, the non-linearity test has to be conducted to find out whether the thresholdtype non-linearity in the time series is present. We use Tsay non-linearity test as in Tsay (1998) and set trimming percentage to $28 \%$. As Tsay recommends we conducted a test with a various trimming values, we rejected $\mathrm{H}_{0}$ at least at the $10 \%$ significance level. Non-linearity test results are summarized in Tab. 1.

\section{Tab. 1: Non-linearity test results}

\begin{tabular}{l|c} 
& test statistics (p-value) \\
\hline Czech Republic & $18.7132(0.095688)$ \\
\hline Slovak Republic & $25.5812(0.012297)$ \\
\hline Hungary & $22.2979(0.034313)$ \\
\hline
\end{tabular}

The test results reject hypothesis of linearity at the $5 \%$ level in case of the Slovak Republic and Hungary but only at the $10 \%$ level in case of the Czech Republic.

If the Tsay test indicates the presence of the non-linearity in the system, the estimation of TVAR model can be carried out. Each regime consists of observations, which were assigned to regimes according to threshold variable and selected threshold value $z^{*}$. Within each regime, the coefficients are estimated by OLS. Thus the TVAR model is linear in the parameters in each regime but the switches from one regime to another regime are responsible for the non-linearity. The choice of the threshold value $z^{*}$ can be randomly selected (though it needs to be empirically verified) (in the case of output gap as threshold variable, we assume the threshold value is equal to 0 that enables us to clearly identify the periods of expansion and recession) or it is possible to apply conditional least squares estimation and select the model minimizing the residual sum of squares (Tsay, 1998). 
Compared to traditional VAR models, TVAR model requires higher number of observations due to independent estimation procedures of parameters in distinct regimes. Commonly used annual data are not in many cases sufficiently large therefore the drawback of this method is that it requires higher frequency data. Alternatively, we could use smooth transition VAR model for estimation of fiscal multipliers in recessions and expansions. Whereas the dynamics of the variables in TVAR approach is modeled by the limited number of states, the dynamics in smooth transition VAR is modeled by the continuum of states. Therefore both approaches suit our needs but due to relative simplicity we choose TVAR approach as our baseline model.

\subsection{Identification Scheme}

A common problem of reduced-form residuals is the correlation. It follows that the variancecovariance matrix of reduced-form residuals is not equal identity matrix. Hence, the shock in one variable affects another variable at the same time. Following Blanchard and Perotti (2002) we assume that the reduced-form residuals are linear combinations of (structural) tax, government spending and output shocks. More specifically fiscal reduced-form residuals respond to unexpected structural fiscal policy shocks and automatic response to output shocks is included as well. Output reduced-form residuals also respond to unexpected fiscal policy shocks together with structural shocks in output. These relationships are captured in the following equations:

$$
\begin{aligned}
& u_{t}^{T}=a_{1} u_{t}^{G D P}+a_{2} \varepsilon_{t}^{G}+\varepsilon_{t}^{T} \\
& u_{t}^{G}=b_{1} u_{t}^{G D P}+b_{2} \varepsilon_{t}^{T}+\varepsilon_{t}^{G} \\
& u_{t}^{G D P}=c_{1} u_{t}^{T}+c_{2} u_{t}^{G}+\varepsilon_{t}^{G D P}
\end{aligned}
$$

where $\varepsilon_{t}=\left(\varepsilon_{t}^{T}, \varepsilon_{t}^{G}, \varepsilon_{t}^{G D P}\right)$ represents the vector of structural shocks. Above mentioned relations between the reduced-form residuals $u_{t}$ and the structural shocks $\varepsilon_{t}$ can be also rewritten to the matrix notation:

$$
A u_{t}=B \varepsilon_{t}
$$

Similarly to Blanchard and Perotti (2002), the determination of parameters is carried out within three steps. In the first step the parameters $a_{1}$ and $b_{1}$ have to be determined. We assume the parameters $a_{1}$ and $b_{1}$ represent the automatic effect of output to fiscal variables on the one hand and the discretionary reaction of fiscal policy to changes in output on the other. Here the usage of quarterly data plays a key role as it is general truth the legislative process of democratic institutions takes a long time. Therefore the adoption of appropriate fiscal policy measure as a reaction to the unexpected output shocks takes more than one quarter what makes a second effect irrelevant. Consequently the parameters capture only the elasticity of net taxes and government spending to output. Unlike the Blanchard and Perotti (2002) we decided to calibrate the parameter $a_{1}$ of surveyed countries. Our decision about the selection of parameter $a_{1}$ is based on the work of Eller (2009), who estimated the elasticity of government revenues for the Slovak Republic (0.88), the Czech Republic (0.99) and Hungary (1.02). Only slightly different values of $a_{1}$ have been applied in the VAR literature based on the Blanchard and Perotti identification scheme. For example, Pécsyová (2013) derived the elasticity of government revenues for the Slovak Republic at 0.76 or Valenta (2011) assumed $a_{1}=0.9$ for the Czech Republic. It is assumed the components of government spending are not sensitive to changes in output, hence we set the elasticity of government spending according to the changes in output, coefficient $b_{1}$, to 0 . The size of $b_{1}$ is also compatible with the calculated coefficients of elasticity of government spending in Eller (2009), which are close to 0 for all three countries.

The second step comprises of estimation of parameters $c_{1}$ and $c_{2}$. Given the parameters $a_{1}$ and $b_{1}$ we can calculate cyclically adjusted (CA) tax residuals as ${ }^{C A} u_{t}^{T}=u_{t}^{T}-a_{1} u_{t}^{G D P}$ and cyclically adjusted spending residuals as ${ }^{C A} u_{t}^{G}=u_{t}^{G}-b_{1} u_{t}^{G D P}=u_{t}^{G}$ (it results from the fact that $\left.b_{1}=0\right)$. Cyclically adjusted residuals are not correlated with $\varepsilon_{t}^{G D P}$ consequently they serve as instruments in the third equation in (2).

Within the estimation of parameters $a_{2}$ and $b_{2}$ it is necessary to determine the character of fiscal policy. Specifically the decision whether government spending reacts to changes in taxes $\left(a_{2}=0, b_{2} \neq 0\right)$ or taxes react to changes in government spending $\left(a_{2} \neq 0, b_{2}=0\right)$ should be taken. Since it is difficult to find arguments that justify first or 
second ordering we performed OLS estimation between ${ }^{C A} u_{t}^{T}$ and ${ }^{C A} u_{t}^{G}$ with both orderings (The results presented in the next section are based on second ordering). The results are not affected by the type of ordering (Upon changed ordering the estimated coefficients were statistically insignificant that is why the size of fiscal multipliers was not altered).

Given the relationship between reducedform residuals and the structural shocks we rewrite the original TVAR model accordingly as

$$
\begin{aligned}
& A Y_{t}=C_{1}(L) Y_{t-1} I\left[z_{t-d} \leq z^{*}\right]+ \\
& +C_{2}(L) Y_{t-1} I\left[z_{t-d}>\mathrm{z}^{*}\right]+B \varepsilon_{t}
\end{aligned}
$$

where $D_{i}(L)=A^{-1} C_{i}(L)$ and $u_{t}=A^{-1} B \varepsilon_{t}$. We assume the shocks $\varepsilon_{t}$ are independent and identically distributed with covariance matrix equal to the identity matrix. $A$ describes the contemporaneous relation among the variables in the vector $Y_{t}$.

Without proper identification scheme shocks do not have economic interpretation. Once the shocks are identified we can calculate generalized impulse response functions and individual fiscal multipliers. Since many authors calculate fiscal multipliers in their studies, correct definition of fiscal multiplier is crucial assumption to preserve comparability between those studies. Fiscal multiplier can be defined as the ratio of change in output $(\Delta y)$ to change in fiscal variable represented by government spending $(\Delta g)$ or taxes $(-\Delta t)$. Following Spilimbergo et al. (2009) several types of fiscal multipliers can be distinguished, depending on the time horizon. The impact multiplier defined as

$$
\frac{\Delta y_{t}}{\Delta g_{t}}
$$

measures the immediate reaction of output to change in fiscal variable. Subsequently cumulative multiplier

$$
\frac{\sum_{j=0}^{N} \Delta y_{t+j}}{\sum_{j=0}^{N} \Delta g_{t+j}}
$$

is considered as the most appropriate measure among those mentioned in Spilimbergo et al.
(2009). It captures the cumulative reaction of output to cumulative change in fiscal variable at some specific horizon $N$.

From identified TVAR models we compute generalized impulse-response functions and fiscal multipliers to estimate effects of fiscal policy shocks ( $1 \%$ and $5 \%$ shocks in government spending and government revenue) on real output in both regimes (lower regime recession gap, upper regime - inflation gap). Effects of the crisis period is also examined by splitting the whole period $(1995 / 1996$ - 2015) into the pre-crisis and crisis periods.

Our sample includes three small and open economies from the region of the Central Europe (CE) that is why Poland is excluded from our sample. As Spilimbergo et al. (2009) suggest, the fiscal multipliers in small and open economies tend to be smaller than in large or medium sized countries. They assume the size of the government spending multiplier for small and open economies is lower than 0.5 and revenue multiplier is lower than 0.25 .

\subsection{Generalized Impulse Response Function}

Impulse response functions in non-linear TVAR model cannot be easily generated from the model parameters as in linear VAR models. To assess the dynamics of the model for which Wold representation does not exist, another method must be applied. Therefore we follow the approach of Koop et al. (1996) and generate generalized impulse response functions (GIRF), which allows us to evaluate effects of fiscal shocks in TVAR model. Due to non-linearity of TVAR model the reaction of variables to exogenous shock depends on the size and the sign of the shocks hitting the economy and the history of variables. The reaction of variables in TVAR models (unlike to traditional linear VAR models) to positive shock and the opposite reaction in case of negative shock need not be symmetric about the x-axis. The same is true for the size of the shock (within non-linear TVAR model a shock of size $2 \%$ does not have exactly twice the effect of a shock of size $1 \%$ ). As a result of large shock the economy can move between the regimes differently in given periods than in the case of smaller shocks, hence it is essential to assess the effects of different shock size. Formally the GIRF can be defined as 


$$
\begin{aligned}
& \text { GIRF }=E\left[Y_{t+m} \mid \varepsilon_{t}, \varepsilon_{t+1}=0, \ldots, \varepsilon_{t+m}=\right. \\
& \left.=0, \Omega_{t-1}\right]-E\left[Y_{t+m} \mid \varepsilon_{t}=0, \varepsilon_{t+1}=\right. \\
& \left.=0, \ldots, \varepsilon_{t+m}=0, \Omega_{t-1}\right]
\end{aligned}
$$

where $Y_{t+m}$ is vector of variables at time $t+m$ and $\Omega_{t-1}$ represents a history. It follows that GIRF is difference between the forecasted path of variable in an economy without shock and forecasted path of the same variable in an economy hit by a shock. Numerical simulations are essential to generate GIRFs. Detailed algorithm is available in Baum et al. (2011) or Ferraresi et al. (2014) or in Appendix A. We conducted our TVAR analysis using the statistical software R.

During numerical simulations occurs the question of generating output gap after each forecasted period. Following the approach of Baum et al (2012) potential output calculated using the HP filter remains constant within the forecasted horizon and is not affected by shocks. As authors point out, changes in potential output are expected to occur predominantly in the longrun and changes within 6 forecasted periods are meaningless. Given the potential output we can simulate the evolution of endogenous variables and calculate the output gap in combination with forecasted path of output variable. In order to calculate GIRFs for every history, we prolonged potential output at the end of the sample.

\subsection{Data}

We perform estimation of TVAR model on quarterly data of the Slovak Republic, the Czech Republic and Hungary. The data are based on ESA 2010 combined with ESA 95. Both the data source and the character of mentioned economies cause the data on quarterly basis are fully available since 1999 . Some data are available from 1995.

Government revenues are defined as total revenues less transfers, subsidies and interest payments and we refer to them as net taxes. Net taxes are calculated as: indirect taxes + direct taxes + capital taxes + social contributions + capital transfers receivable + other current transfers receivable - social benefits - other current transfers payable - capital transfers payable - subsidies. Other current revenue receivable, capital transfers receivable, other transfers payable, capital transfers payable are not available since 1995Q1 to 1998 Q4 on quarterly basis. However, the data are available on annual basis, therefore we proceed to interpolation and in some cases (gross fixed capital formation available before 1999 in the Czech Republic and Hungary) the data were obtained by keeping the same share as in 1999. Also we did not include capital transfers into calculation of net taxes (similarly as in Baum (2012)) for Czech Republic due to many outliers in those series. As a government expenditure indicator we used government consumption expenditure together with government gross fixed capital formation. Specifically the structure of government expenditures and net taxes is similar to Borg (2014), who based the estimation of fiscal multipliers on ESA 95 and used same identification scheme. All variables are deflated with the output (GDP) deflator and seasonally adjusted using X-13 ARIMA-SEATS developed by the United States Census Bureau.

In related literature authors employ mainly two measures of economic activity, serving as threshold variable - output gap and output growth rate. In our study we will present and discuss the results based on output gap. We estimated output gap with the use of HodrickPrescott filter $(\lambda=1,600)$ on the real output

\section{Tab. 2: ADF test results}

\begin{tabular}{l|r|r|r|r} 
& \multicolumn{4}{|c}{ Number of lags (t-statistics, p-value) } \\
\cline { 2 - 5 } & \multicolumn{1}{|c|}{ T } & \multicolumn{1}{c}{ G } & \multicolumn{1}{c}{ output } & output gap \\
\hline Czech Republic & $3(-3.75302,0.0050)$ & $0(-10.85474,0.0001)$ & $1(-5.59009,0.0000)$ & $4(-3.65595,0.0067)$ \\
\hline Slovak Republic & $0(-10.9084,0.0001)$ & $3(-4.47900,0.0005)$ & $0(-11.55891,0.0001)$ & $0(-4.35061,0.0007)$ \\
\hline Hungary & $3(-5.33113,0.0000)$ & $0(-6.79142,0.0000)$ & $0(-4.47576,0.0005)$ & $1(-3.79207,0.0044)$ \\
\hline
\end{tabular}


time series. Output gap enters the model in the percentage of potential output.

We estimated TVAR model using variables in the first differences but firstly we applied logarithm to non-stationary series. We test whether the variables follow a random walk with drift for which we used Augmented Dickey-Fuller (ADF) test where the number of lags was chosen according to Schwarz information criterion (SIC). The ADF test indicates that all differenced series are stationary, so we can reject the null hypothesis of unit root. The threshold variable is also assumed to be stationary. Results of ADF tests are summarized in Tab. 2.

\section{Results and Discussion}

The decision on the number of lags in TVAR model was based on standard information criteria. According to Akaike information criterion (AIC), Hannan-Quinn (HQ) and Schwarz information criterion (SIC) the optimal lag length for all three countries is 1 . However the issue of selecting the optimal lag length is slightly more complicated in non-linear framework. Since we have the limited amount of observations for each country the selection of one lag seems to be the most appropriate alternative. Tab. 3 summarizes the main information concerning the data and results of estimation.

\section{Tab. 3: TVAR estimation}

\begin{tabular}{l|c|c|c|c} 
& sample & $\begin{array}{c}\text { lag } \\
\text { length }\end{array}$ & $\begin{array}{c}\text { threshold value } \\
\text { (estimated) }\end{array}$ & $\begin{array}{c}\text { number of observation in } \\
\text { recession - expansion regime }\end{array}$ \\
\hline Czech Republic & $1996 \mathrm{Q} 1-2015 \mathrm{Q} 1$ & 1 & 1.09316 & $52-24$ \\
\hline Slovak Republic & $1995 \mathrm{Q} 2-2015 \mathrm{Q} 3$ & 1 & -0.51883 & $45-36$ \\
\hline Hungary & $1995 \mathrm{Q} 2-2015 \mathrm{Q} 3$ & 1 & 0.25374 & $55-26$ \\
\hline
\end{tabular}

Our results from estimated TVAR model for CE3 countries indicate that the distribution of all observations mostly prevail in the lower regime while the number of observations in upper regime is still sufficient to preserve the robustness of the results that reveal the effects of fiscal policy shocks in both recession and expansion regimes. Moreover, higher representation of observations in the regime of recession (occurrence of the negative output gap represented $68 \%$ of all observations in the Czech Republic, 55 percent in the Slovak Republic and 68 percent in Hungary) indicates that countries operated during the most of the analyzed period below the potential real output. As result, the higher importance of the fiscal policy shocks and their effect on the real output in the lower regime should be considered in the concluding remarks.

\subsection{Impulse-Response Functions}

In the following figures (Fig. 1, 2 and 3) we summarize the responses of fiscal variables and particularly output to 1 percentage positive government spending and revenue shocks in observed economies. Cumulative response of output due to the government spending shock in the Czech Republic and Hungary tends to be higher in a recession than expansion during the whole forecasted period. Differences within regimes reach considerable proportions and in case of the Czech Republic cumulative response of output tends to be even negative in upper regime. Similar results in both countries are valid for responses of output to the revenue shock, i.e. higher revenue multipliers in recession. The response of output to positive revenue shock is negative in Hungary in both regimes. In case of the Czech Republic the impact revenue multiplier is 0.97 within both regimes regardless of the shock size. However, the cumulative revenue multiplier declines sharply and at horizon of 4 and 6 quarters its size is close to zero or even negative in upper regime. TVAR model estimated on the Slovak data indicates that fiscal stimuli (government spending shocks) were more effective in terms of the size of fiscal multipliers in the regime of expansion. 


\section{Ekonomie}

\section{Fig. 1: GIRFs for $1 \%$ shock in government spending and net taxes - SR}

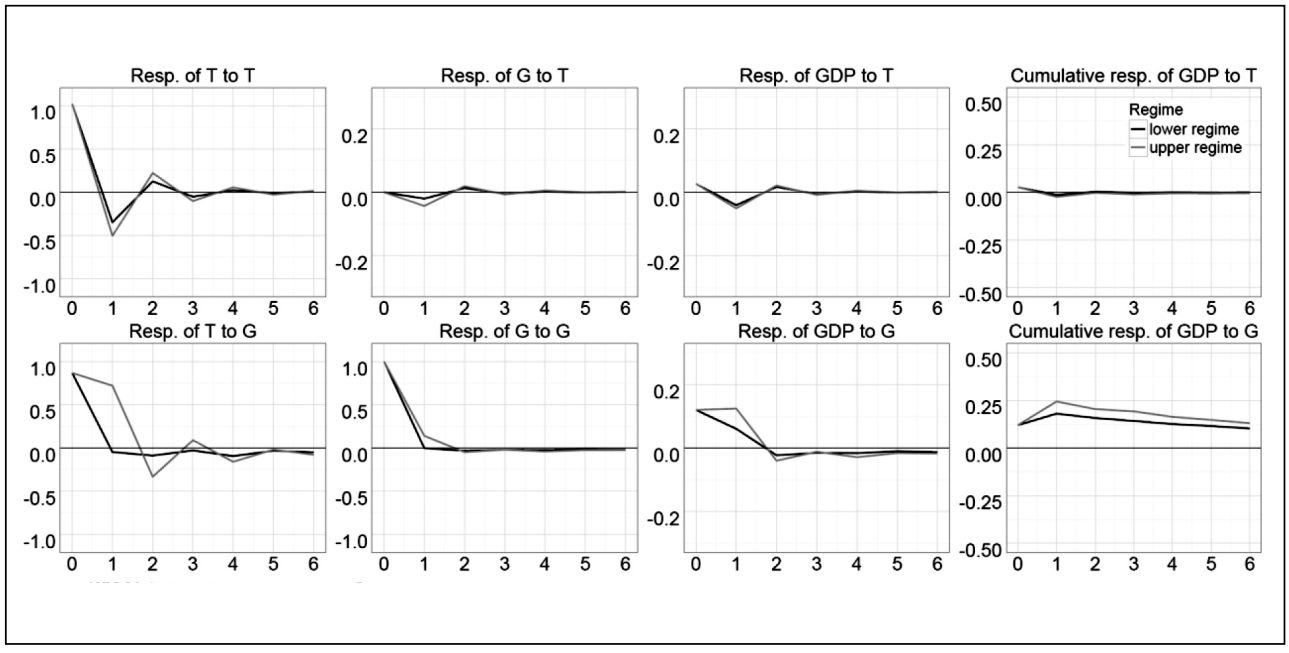

Source: author's calculations

Note: Curves represent responses (changes in percentage) of real output to the positive fiscal shocks in each individual country from the EU3 group. All shocks are standardized to one-percent shocks. Horizontal axis depict quarters.

\section{Fig. 2: GIRFs for $1 \%$ shock in government spending and net taxes $-\mathrm{CZ}$}
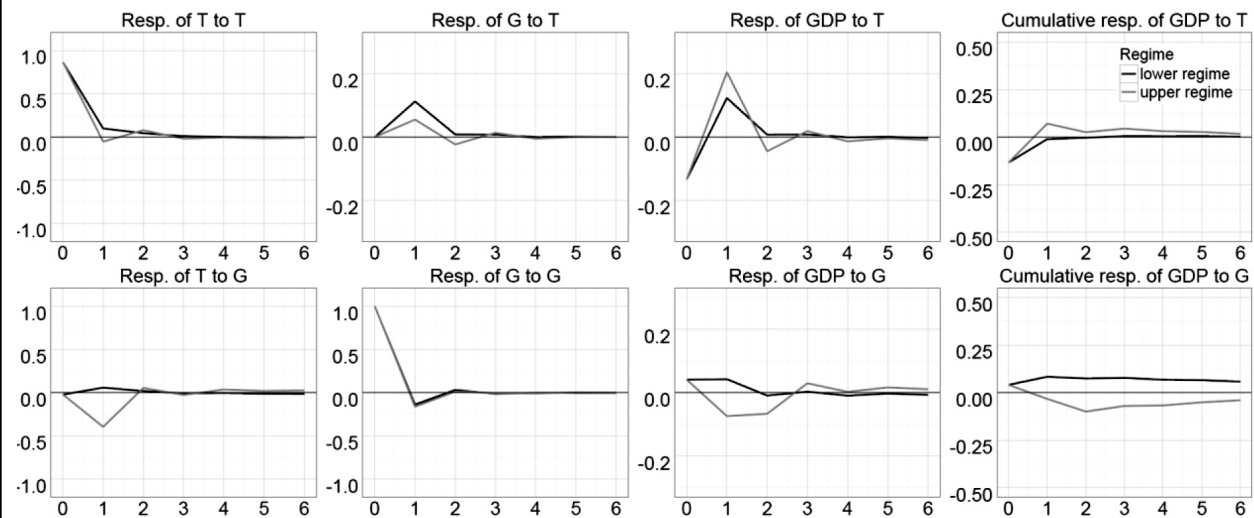

Source: author's calculations

Note: Curves represent responses (changes in percentage) of real output to the positive fiscal shocks in each individual country from the EU3 group. All shocks are standardized to one-percent shocks. Horizontal axis depict quarters. 


\section{Fig. 3: GIRFs for $1 \%$ shock in government spending and net taxes - HU}

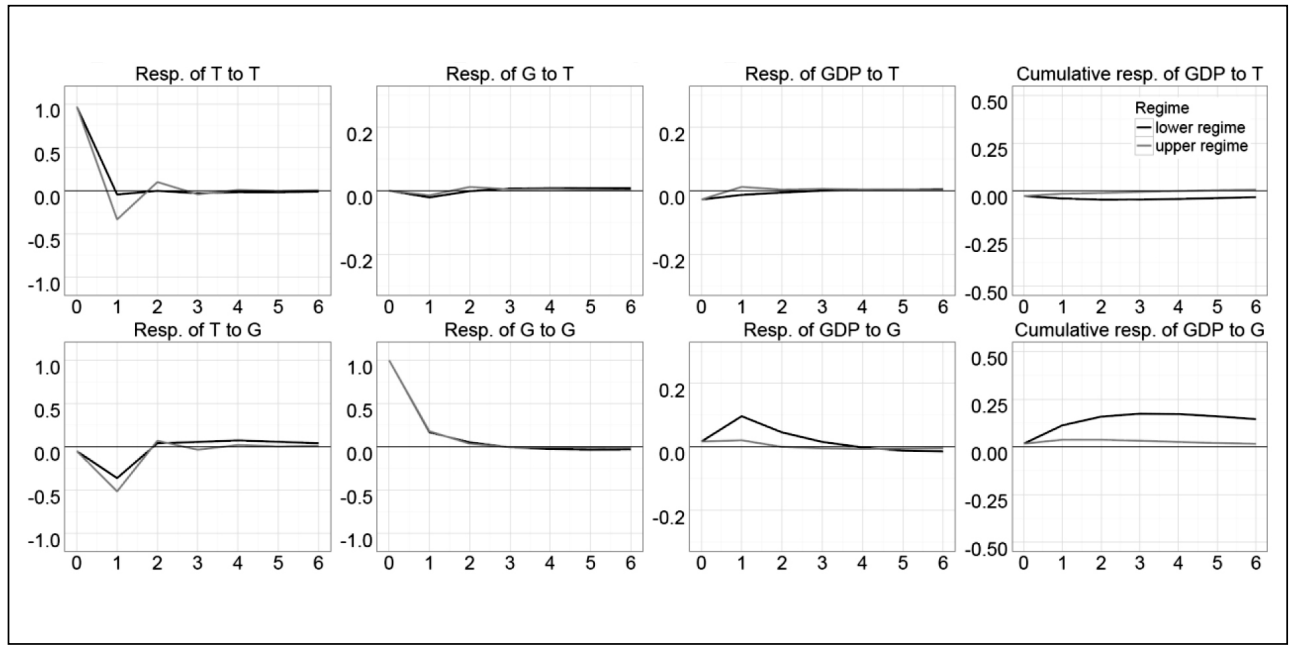

Source: author's calculations

Note: Curves represent responses (changes in percentage) of real output to the positive fiscal shocks in each individual country from the EU3 group. All shocks are standardized to one-percent shocks. Horizontal axis depict quarters.

The positive government expenditure shock (increase in government expenditures) was followed by an increase in the real output in the lower regime in all three countries. As a result, the fiscal expansion in bad times (recession) provides beneficial incentives and boosts the real output in the whole group. Despite some minor differences among individual countries our results correspond with empirical evidence. Spending multipliers differed between regimes and reached higher values in the Slovak Republic in comparison with the previous two countries. However, the responsiveness of the real output to the government spending shock in the upper regime revealed some differences that need to be explained (Ramey \& Zubairy, 2014; Ilzetzki, Mendoza, \& Végh, 2011). It seems that fiscal expansion in good times (upper regime) provides mixed evidence about the effects of fiscal stimuli in economies operating above the potential product (Heppke-Falk, Tenhofen, \& Wolff, 2006). The real output in the Slovak Republic increased even more after the positive government spending shock (in comparison with a lower regime), an increase of the real output in Hungary was just negligible while the real output in the Czech Republic temporarily decreased.
Revealed mixed evidence about the role of fiscal stimuli in CE3 countries in the upper regime indicates questionable and even country specific implications of expansionary expenditure based fiscal redistribution (Tsibouris, Horton, Flanagan, \& Maliszewski, 2006). According to some authors, fiscal expansion may increase productive capacity of the country that is why positive effects of expenditure policies may be significant even in good times (Ramey \& Zubairy, 2014). While the size of fiscal multipliers at this stage strongly depend on the structure of government expenditures (Ćorić, Šimović, \& Deskar-Škrbić, 2015), the risks of induced inflationary pressures in the country at the peak of its performance (Petrevski, Bogoev, \& Tevdovski, 2015) may easily turn into the overheating of the economy followed by an inevitable cool-down and thus a significant reduction in the multiplication process. As a result, pro-cyclical patterns in the fiscal policies conducted via increase in the public expenditures in good times reduce the real output growth rates in Hungary and even deteriorates the real output in the Czech Republic. Finally, the Slovak Republic is the only example in our sample of countries where the fiscal expansion conducted in the upper regime 
stimulates the real output growth rates though it may induce an unfavorable crowding-out effect and/or an increase in the current account deficit in the long run (Giuliodori \& Beetsma, 2004).

Our results also indicate that the overall vulnerability of the real output to an increase in the taxes was generally small and short-term. Moreover, differences in the revenue multipliers between regimes were also small and close to zero after one year. We suggest that reduced countercyclical effects (upper regime) of the revenue based fiscal policy indicate reduced maneuverability of fiscal authority to reduce the risk of overheating in good times via taxing. While generally surprising (Romer \& Romer, 2007), these results even emphasize increased role of external sector in determining the overall performance of the small opened economies in our sample. On the other hand, reduced and shortterm negative responsiveness of the real output to the revenue based fiscal shocks (increase in taxes) in CE3 countries (lower regime) represents good signal for fiscal authorities consolidating public finance. This observation corresponds to empirical evidence in some countries (Wöhlbier, Astarita, \& Mourre, 2014) though due to risks associated with deepening the recession during the bad times this type of policy is generally not recommended.

To check the robustness of results we also performed certain modification. We fixed the threshold value to 0 and re-estimated TVAR model for all three countries. This implies that the assignment of certain observation into lower or upper regime is determined by the output gap in the previous quarter. If the economy is in positive output gap in the previous quarter then the observation in current quarter will be assigned to upper regime and vice versa. The resulted redistribution of observations changed only slightly for all three countries (HU - 49 observations in lower regime and 32 in upper regime; SK - 53 in lower regime and 28 in upper regime; $C Z-45$ in lower regime and 31 in upper regime) compared with an estimate by minimization of residual sum of squares. However, the generated impulse responses were not significantly affected by this

\section{Fig. 4: Cumulative response of output before and during the economic crisis}

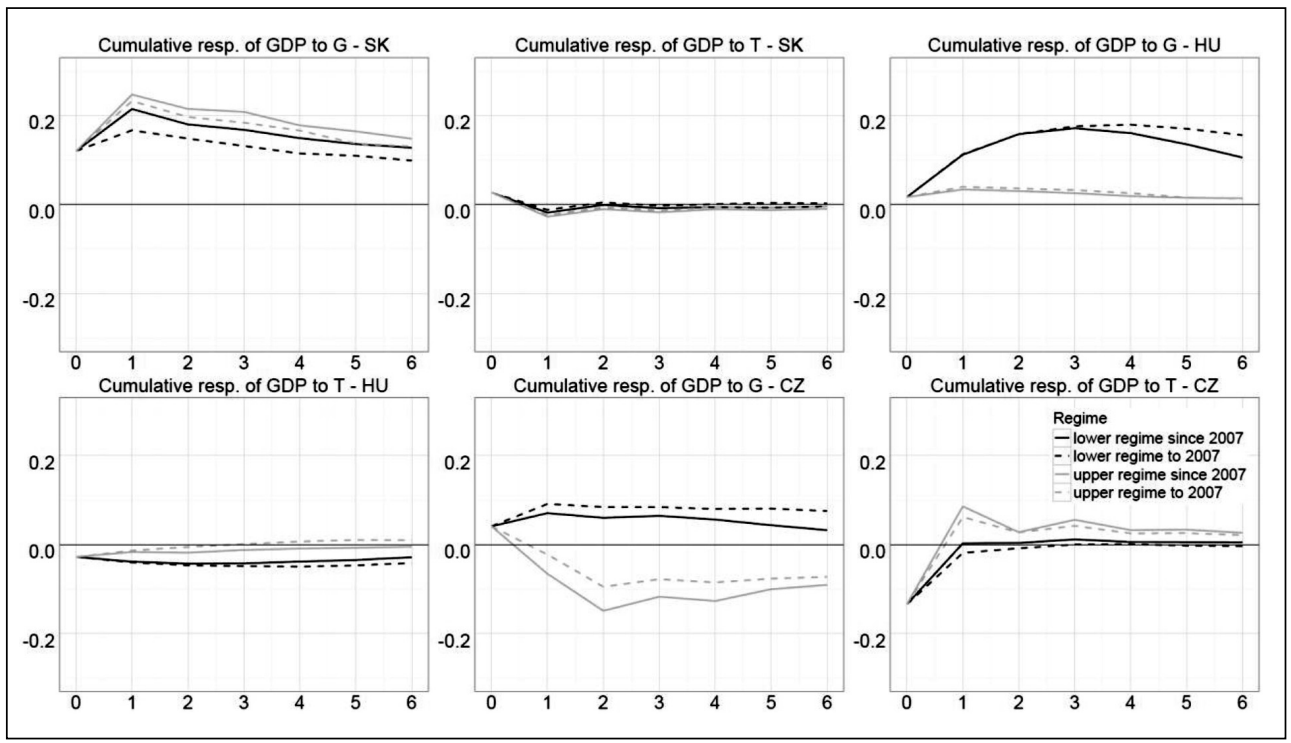

Source: author's calculations

Note: Curves represent responses (changes in percentage) of real output to the positive fiscal shocks in each individual country from the EU3 group. All shocks are standardized to one-percent shocks. Horizontal axis depict quarters. 
modification and the size of fiscal multipliers remained generally unchanged.

Since we see certain risk in data interpolation we decided to analyze qualitative results of our paper without observations before 1999Q1. Reduced number of observations may cause biased estimates but the fact remains that the fiscal multipliers in the Czech Republic and Hungary are higher in recession, while in Slovakia fiscal multipliers are higher in expansion.

Simulation of generalized impulse responses for each quarter enables us to estimate the fiscal multipliers for specific subperiods. In order to examine the effects of the crisis period on estimated responsiveness of the real output to the fiscal variables generated impulse responses were divided into two consecutive periods 1995Q2-2007Q4 and 2008Q1-2015Q3 (1996Q2-2007Q1 and 2008Q1-2015Q1 for the Czech Republic). Average GIRF were then computed for each given period and regime. Figure 4 captures the cumulative reaction of output to a 1 percentage shock to government spending and net taxes for two different periods. Different impulse responses are not the result of change in parameters (the estimated parameters remain unchanged) the algorithm simply takes into account the different starting conditions during generating impulse responses.

Crisis period moderately affected responses of output and the size of fiscal multipliers (see Appendix B). In two countries (the Czech Republic and Hungary) the period after the crisis is characterized by reduced fiscal multipliers compared to the period before the crisis. On the other hand, the response of the Slovak output to fiscal shocks tends to be higher in period after 2007Q4. The largest differences between spending multipliers in different periods occurred in the Czech Republic where, in some periods, the differences in the size of fiscal multiplier exceeded 0.15 percentage points.

Estimated cumulative impulse-response functions are converted to fiscal multipliers using the country's sample mean of outputspending (output-revenues) ratio. Fiscal multipliers are summarized in Tab. 4.

\section{Tab. 4: Cumulative fiscal multipliers}

\begin{tabular}{|c|c|c|c|c|}
\hline \multirow[b]{2}{*}{ Slovak Republic } & \multicolumn{2}{|c|}{4 quarters } & \multicolumn{2}{|c|}{6 quarters } \\
\hline & $\begin{array}{c}1 \%(5 \%) \\
\text { spending shock }\end{array}$ & $\begin{array}{c}1 \%(5 \%) \\
\text { revenue shock }\end{array}$ & $\begin{array}{c}1 \%(5 \%) \\
\text { spending shock }\end{array}$ & $\begin{array}{c}1 \%(5 \%) \\
\text { revenue shock }\end{array}$ \\
\hline Lower regime & $0.60(0.65)$ & $0.01(0.02)$ & $0.52(0.56)$ & $0.02(0.02)$ \\
\hline Upper regime & $0.72(0.78)$ & $0.10(0.09)$ & $0.63(0.68)$ & $0.09(0.08)$ \\
\hline \multirow[b]{2}{*}{ Hungary } & \multicolumn{2}{|c|}{4 quarters } & \multicolumn{2}{|c|}{6 quarters } \\
\hline & $\begin{array}{c}1 \%(5 \%) \\
\text { spending shock }\end{array}$ & $\begin{array}{c}1 \%(5 \%) \\
\text { revenue shock }\end{array}$ & $\begin{array}{c}1 \%(5 \%) \\
\text { spending shock }\end{array}$ & $\begin{array}{c}1 \%(5 \%) \\
\text { revenue shock }\end{array}$ \\
\hline Lower regime & $0.58(0.58)$ & $0.24(0.24)$ & $0.52(0.51)$ & $0.20(0.19)$ \\
\hline Upper regime & $0.10(0.08)$ & $0.05(0.02)$ & $0.06(0.05)$ & $0.02(-0.01)$ \\
\hline \multirow[b]{2}{*}{ Czech Republic } & \multicolumn{2}{|c|}{4 quarters } & \multicolumn{2}{|c|}{6 quarters } \\
\hline & $\begin{array}{c}1 \%(5 \%) \\
\text { spending shock }\end{array}$ & $\begin{array}{c}1 \%(5 \%) \\
\text { revenue shock }\end{array}$ & $\begin{array}{c}1 \%(5 \%) \\
\text { spending shock }\end{array}$ & $\begin{array}{c}1 \%(5 \%) \\
\text { revenue shock }\end{array}$ \\
\hline Lower regime & $0.33(0.31)$ & $0.06(0.08)$ & $0.28(0.27)$ & $0.06(0.07)$ \\
\hline Upper regime & $-0.32(-0.34)$ & $-0.15(-0.12)$ & $-0.23(-0.22)$ & $-0.11(-0.09)$ \\
\hline
\end{tabular}


With increasing size of the shock from $1 \%$ to $5 \%$ only small changes in estimated fiscal multipliers occurred. The most significant differences are mainly the result of higher spending shocks in the Slovak Republic while spending and revenue multipliers in case of Hungary remained almost unchanged. Following our results we may conclude that the size of the shock does not represent a significant determinant of fiscal multipliers in our sample of the countries. Furthermore we analyzed the differences in response of the output due to the type of the shock, i.e. whether it is positive or negative. However, the effect of negative 1 percentage shock to government spending and revenues seems to be similar as the same shock with positive sign. The differences were even smaller in comparison with the previous analysis concerning the shock size (because of lack of space the detailed results of negative shock effects are not reported).

\section{Conclusions}

In the paper we have analyzed effects of the fiscal policy shocks in CE3 countries by employing TVAR model. Our results indicate that the overall responsiveness of the real output to the fiscal adjustments as well as the size of fiscal multipliers generally corresponds to the recent findings in the empirical literature. However, estimated model that enabled us to examine effects of the changes in government expenditures and taxes during good times (upper regime) and bad times (lower regime) revealed crucial implications of fiscal adjustments according to the phase of the business cycle in our sample our countries.

Responsiveness of the real output to the expenditure based fiscal shocks was generally higher (though different) in all three countries. Differences became even more significant when comparing the results for both regimes. While in the recession (lower regime) the real output increased after the positive government spending shock (the most significantly in the Slovak Republic and the most durable in Hungary), results for the expansion (higher regime) revealed mixed evidence. As a result, pro-cycle patterns of the expenditure based fiscal expansion in the good times reduced the real output growth rates in Hungary and even deteriorated the real output in the Czech Republic. Contrary, fiscal expansion in good times was followed by an increased dynamic in the real output growth rates in the Slovak Republic. It seems that the fiscal expansion in the Slovak Republic in good times might have the positive effect on the productive capacities, however, risks of inflationary pressures, crowding-out effect and current account deficit still makes pro-cyclical patterns in the expenditure based fiscal adjustments in good times less favorable.

Surprisingly, responsiveness of the real output to the revenue based fiscal shocks was small and of a short-term durability in all CE3 countries. Our estimates indicate reduced benefits of countercyclical fiscal adjustments in good times, negligible deteriorating effects on the real output favor revenue based consolidating adjustments in bad times. While generally disputable, these results correspond to both theoretical (Friedman, 1957) and empirical (Wöhlbier, Astarita, \& Mourre, 2014) evidence in the small opened economies. Moreover, vulnerability of the real output to the changes in the different tax rates in both regimes will be investigated in our further research.

Finally, splitting the whole examined period into two sub-periods revealed interesting implications of the crisis period on the estimated results. Differences in the responsiveness of the real output are slightly higher in case of the expenditure based fiscal adjustments in all three countries (in terms of both, regimes and sub-periods). In the Czech Republic and Hungary our estimates confirmed reduced role of fiscal authorities in determining the real output dynamics during the crisis years as indicated by both impulse-response analysis as well as the size of fiscal multipliers. However, the Slovak experience from period-based approach confirmed regime based differences in comparison with remaining two economies. This finding corresponds with economic crisis intensified demand driven redistributive (or expenditure shifting) effects (Mirdala, 2015). As a result, the crisis period reduced the role of public expenditures in the real output determination in the Czech Republic and with a less intensity in Hungary while in the Slovak Republic the role of public spending increased and even induced an increase in the productive capacity.

This paper was written in connection with scientific project VEGA no. 1/0994/15. Financial 
support from this Ministry of Education's scheme is also gratefully acknowledged.

\section{References}

Afonso, A., Baxa, J., \& Slavik, M. (2011). Fiscal Developments and Financial Stress: A Threshold VAR Analysis [ECB Working Paper Series, No. 1319]. Frankfurt am Main: European Central Bank.

Alesina, A., \& Ardagna, S. (2009). Large Changes in Fiscal Policy: Taxes vs. Spending [National Bureau of Economic Research Working Paper, No. 15438]. New York: National Bureau of Economic Research. doi:10.3386/ w15438.

Auerbach, A. J., \& Gorodnichenko, Y. (2012). Measuring the Output Responses to Fiscal Policy. American Economic Journal: Economic Policy, 4(2), 1-27. doi:10.1257/pol.4.2.1.

Barrios, S., Langedijk, S., \& Penc, L. (2010). EU Fiscal Consolidation after the Financial Crisis. Lesson from Past Experience [EC Economic Paper, No. 418/2010]. Brussels: European Commission.

Baum, A., \& Koester, G. B. (2011). The Impact of Fiscal Policy on Economic Activity Over the Business Cycle - Evidence from a Threshold VAR Analysis [DB Discussion Paper, No. 03/2011]. Frankfurt: Deutsche Bundesbank.

Baum, A., Poplawski-Ribeiro, M., \& Weber, A. (2012). Fiscal Multipliers and the State of the Economy [IMF Working Paper Series, No. 286/2012]. Washington D.C.: International Monetary Fund, 30 p. doi:10.5089/9781475565829.001.

Benčík, M. (2014). Dual Regime Fiscal Multipliers in Converging Economies A Simplified STVAR Approach [NBS Working Paper Series, No. 2/2014]. Bratislava: National Bank of Slovakia.

Blanchard, O., \& Perotti, R. (2002). An Empirical Characterization of the Dynamic Effects of Changes in Government Spending and Taxes on Output. The Quarterly Journal of Economics, 117(4), 1329-1368. doi:10.1162/003355302320935043.

Borg, I. (2014). Fiscal Multipliers in Malta [CBM Working Paper Series, No. 06/2014]. Valletta: Central Bank of Malta.

Boiciuc, I. (2016). The Macroeconomic Effects of Fiscal Policy. A BVAR Approach. Review of Economic and Business Studies, 14(2014), 163-169.
Burnside, C., Eichenbaum, M., Fisher, J. (2003). Fiscal Shocks and their Consequences. Journal of Economic Theory, 115(1), 89-117. doi:10.1016/S0022-0531(03)00252-7.

Borys, P., Ciżkowicz, P., \& Rzońca, A. (2013). Panel Data Evidence on the Effects of Fiscal Impulses in the EU New Member States [NBP Working Paper Series, No. 161/2013]. Warsaw: National Bank of Poland.

Caggiano, G., Castelnuovo, E., Colombo, V., \& Nodari, G. (2015). Estimating Fiscal Multipliers: News From a Nonlinear World. The Economic Journal, 125(584), 746-776. doi:10.1111/ecoj.12263.

Caldara, D., \& Camps, C. (2008). What Are the Effects of Fiscal Policy Shocks [ECB Working Paper Series, No. 877/2008]. Frankfurt am Main: European Central Bank.

Callegari, G., Melina, G., \& Batini, N. (2012). Successful Austerity in the United States, Europe and Japan [IMF Working Paper Series, No. 90/2012]. Washington D.C.: International Monetary Fund. doi:10.5089/9781475505382.001.

Ćorić, T., Šimović, H., \& Deskar-Škrbić, M. (2015). Monetary and Fiscal Policy Mix in a Small Open Economy. Economic Research - Ekonomska Istraživanja, 28(1), 407-421. doi:10.1080/1331677X.2015.1059073.

Corsetti, G., Kuester, K., Meier, A., \& Müller, G. J. (2010). Debt Consolidation and Fiscal Stabilization of Deep Recessions. American Economic Review: Papers \& Proceedings, 100(2), 41-45. doi:10.1257/aer.100.2.41.

Cos, P. H., Moral-Benito, E. (2015). Fiscal multipliers in turbulent times: The case of Spain. Empirical Economics, 50(4), 1589-1625. doi:10.1007/s00181-015-0969-0.

Cournède, B., \& Gonand, F. (2006). Restoring Fiscal Sustainability in the Euro Area: Raise Taxes or Curb Spending? [OECD Economics Department Working Paper Series, No. 520/2006]. Paris: Organization for Economic Cooperation and Development.

Cauresma, J. C., Eller, M., \& Mehrotra, A. (2011). The Economic Transition of Fiscal Policy Shocks from Western to Eastern Europe: Focus on European Economic Integration. Focus on European Economic Integration, Q2/11, 44-67.

Dumitrescu, B. A. (2015). The Fiscal Consolidation Consequences and Economic Growth in Romania. Romanian Journal of Economic Forecasting, 18(3), 136-151.

Eller, M. (2009). Fiscal Position and Size 
of Automatic Stabilizers in the CESEE EU Member States: Implications for Discretionary Measures. Focus on European Economic Integration, 2(2009), 78-84.

European Commission. (2014). Report on Public Finances in EMU - 2014 [European Economy No. 9/2014]. Brussels: European Commission.

Farkašovský, V., Lawson, C. W., \& Zimková, E. (2015). A Debt Sustainability Analysis of the Czech Republic and the Slovak Republic: A Non Parametric Approach. E\&M Ekonomie a Management, 18(3), 18-29. doi:10.15240/ tul/001/2015-3-002.

Fernandez, F. C., \& Hernandez de Cos, P. (2006). The Economic Effects of Exogenous Fiscal Shocks in Spain a SVAR Approach [ECB Working Paper Series, No. 647/2006]. Frankfurt am Main: European Central Bank.

Ferraresi, T., Roventini, A., \& Fagiolo, G. (2014). Fiscal Policies and Credit Regimes: A TVAR Approach. Journal of Applied Econometrics, 30(7), 1047-1072. doi:10.1002/ jae.2420.

Filipovski, V., Fiti, T., \& Trenovski, B. (2016). Efficiency of the Fiscal Policy and the Fiscal Multipliers - The Case of the Republic of Macedonia. Economic Studies, 2016(1), 3-23.

Franta, M. (2012). Macroeconomic Effects of Fiscal Policy in the Czech Republic: Evidence Based on Various Identification Approaches in a VAR [CNB Working Paper Series, No. 13/2012]. Prague: Czech National Bank.

Friedman, M. (1957). The Permanent Income Hypothesis. In M. Friedman (Ed.), A Theory of the Consumption Function (pp. 20-37). Princeton: Princeton University Press.

Giuliodori, M., \& Beetsma, R. (2004). What are the Spill-overs from Fiscal Shocks in Europe? An Empirical Analysis [ECB Working Paper Series, No. 325/2004]. Frankfurt am Main: European Central Bank.

Heppke-Falk, K., Tenhofen, J., \& Wolff, G. B. (2006). The Macroeconomic Effects of Exogenous Fiscal Policy Shocks in Germany: A Disaggregated SVAR Analysis [Deutsche Bundesbank Discussion Paper No. 41/2006]. Frankfurt am Main: Deutsche Bundesbank.

Ilzetzki, E., Mendoza, E. G., \& Végh, C. A. (2011). How Big (Small?) are Fiscal Multipliers? [NBER Working Paper Series, No. 16479]. Cambridge: National Bureau of Economic Research. doi:10.3386/w16479.
Koop, G., Pesaran, M., \& Potter, S. M. (1996). Impulse response analysis in nonlinear multivariate models. Journal of Econometrics, 74(1), 119-147. doi:10.1016/03044076(95)01753-4.

Mirdala, R. (2015). Real Exchange Rates, Current Accounts and Competitiveness Issues in the Euro Area. Journal of Applied Economic Sciences, 10(7), 1093-1124

Mountford, A., \& Uhlig, H. (2008). What Are the Effect of Fiscal Policy Shocks? [NBER Working Paper Series, No. 14551]. New York: National Bureau of Economic Research. doi:10.3386/w14551.

Pécsyová, M. (2013). Odhad vplyvu fiškálnej konsolidácie na rast HDP v SR. Biatec, 21(4), 20-27.

Perotti, R. (2005). Estimating the Effects of Fiscal Policy in OECD Countries [ECB Working Paper Series, No. 168/2005]. Frankfurt am Main: European Central Bank.

Petrevski, G., Bogoev, J., \& Tevdovski, D. (2015). Fiscal and Monetary Policy Effects in Three South Eastern European Economies. Empirical Economics, 50(2), 415-441. doi:10.1007/s00181-015-0932-0.

Ramey, V. A., \& Zubairy, S. (2014). Government Spending Multipliers in Good Times and in Bad: Evidence from U.S. Historical Data [NBER Working Paper Series, No. 20719]. New York: National Bureau of Economic Research. doi:10.3386/w20719.

Romer, C. D., \& Romer, D. H. (2007). The Macroeconomic Effects of Tax Changes: Estimates Based on a New Measure of Fiscal Shocks [NBER Working Paper Series, No. 13264]. New York: National Bureau of Economic Research. doi:10.3386/w13264.

Spilimbergo, A., Schindler, M., \& Symansky, S. (2009). Fiscal Multipliers. IMF Staff Position Notes, 2009(11). doi:10.5089/9781462372737.004.

Tsay, R. S. (1998). Testing and Modeling Multivariate Threshold Models. Journal of the American Statistical Association, 93(443), 1188-1202. doi:10.1080/01621459.1998.1047 3779.

Tsibouris, G. C., Horton, M. A., Flanagan, M. J., \& Maliszewski, W. S. (2006). Experience with Large Fiscal Adjustments [IMF Occasional Paper Series, No. 246/2006]. Washington, D.C.: International Monetary Fund.

Valenta, V. (2011). Interactions between Fiscal Policy and Real Economy in the Czech 


\section{Economics}

Republic: A Quantitative Analysis (doctoral dissertation). University of Economics, Prague.

Wöhlbier, F., Astarita, C., \& Mourre, G. (2014). Consolidation on the Revenue Side and Growth-friendly Tax Structures: An Indicator Based Approach [European Economy, Economic Papers, No. 513/2014]. Brussels: European Commission. doc. Ing. Rajmund Mirdala, PhD. Technical University of Košice Faculty of Economics Department of Economics rajmund.mirdala@tuke.sk

Ing. Martin Kameník Technical University of Košice Faculty of Economics Department of Economics martin.kamenik@tuke.sk 


\section{Ekonomie}

\section{Appendix A: Algorithm for computing GIRF}

1. Pick a history $\Omega_{t-1}^{r}$, where $r=1,2, \ldots, R$. The history represents the actual value of the lagged endogenous variable at a date $r$. Note that $R$ refers to the values corresponding to the regime the impulse responses are calculated for.

2. Draw the residuals $\varepsilon_{t+m}^{*}$ with replacement from the estimated residuals $\varepsilon_{t}$ of TVAR model.

3. Given drawn residuals, $\Omega_{t-1}^{r}$ and model parameters $D_{1}$ and $D_{2}$, simulate the evolution of $Y_{t+j}$, $j=0,1, \ldots, m$. We yield $Y_{t+m}\left(\Omega_{t-1}^{r} \mid \varepsilon_{t+m}^{*}\right)$.

4. If we want to shock $i$ th variable add a shock $\varepsilon_{0}$ on $i$ th element of the firstly drawn residual.

5. Given drawn residuals $\varepsilon_{t+m}^{*}$ modified by shock $\varepsilon_{0}, \Omega_{t-1}$ and model parameters $D_{1}$ and $D_{2}$, simulate the evolution of $Y_{t+j}, j=0,1, \ldots, m$. We yield $Y_{t+m}\left(\Omega_{t-1}^{r} \mid \varepsilon_{0}, \varepsilon_{t+m}^{*}\right)$.

6. Repeat steps 2 to $5 B$ times $(B=400)$.

7. Calculate differences between shocked and non-shocked path. Subsequently take the average of computed differences.

8. Repeat steps 1 to 7 for all histories.

9. Compute the average GIRF as

$$
Y_{t+m}\left(\varepsilon_{0}\right)=\frac{1}{R} \sum_{r=1}^{R} \frac{Y_{t+m}\left(\Omega_{t-1}^{r} \mid \varepsilon_{0}, \varepsilon_{t+m}\right)-Y_{t+m}\left(\Omega_{t-1}^{r} \mid \varepsilon_{t+m}^{*}\right)}{B}
$$




\section{Appendix B: Fiscal multipliers before and during crisis period}

\begin{tabular}{|c|c|c|c|c|}
\hline \multirow[b]{2}{*}{ Slovak Republic } & \multicolumn{2}{|c|}{4 quarters } & \multicolumn{2}{|c|}{6 quarters } \\
\hline & $\begin{array}{c}\text { before } 2007 \\
\text { (after 2007) } \\
\text { spending shock }\end{array}$ & $\begin{array}{l}\text { before 2007 } \\
\text { (after 2007) } \\
\text { revenue shock }\end{array}$ & $\begin{array}{c}\text { before } 2007 \\
\text { (after 2007) } \\
\text { spending shock }\end{array}$ & $\begin{array}{c}\text { before 2007 } \\
\text { (after 2007) } \\
\text { revenue shock }\end{array}$ \\
\hline Lower regime & $0.55(0.65)$ & $0.00(0.05)$ & $0.47(0.58)$ & $0.01(0.04)$ \\
\hline \multirow[t]{2}{*}{ Upper regime } & $0.66(0.75)$ & $0.06(0.08)$ & $0.57(0.68)$ & $0.05(0.07)$ \\
\hline & \multicolumn{2}{|c|}{4 quarters } & \multicolumn{2}{|c|}{6 quarters } \\
\hline Hungary & $\begin{array}{c}\text { before } 2007 \\
\text { (after 2007) } \\
\text { spending shock }\end{array}$ & $\begin{array}{l}\text { before 2007 } \\
\text { (after 2007) } \\
\text { revenue shock }\end{array}$ & $\begin{array}{c}\text { before } 2007 \\
\text { (after 2007) } \\
\text { spending shock }\end{array}$ & $\begin{array}{c}\text { before } 2007 \\
\text { (after 2007) } \\
\text { revenue shock }\end{array}$ \\
\hline Lower regime & $0.59(0.52)$ & $0.25(0.21)$ & $0.55(0.40)$ & $0.22(0.15)$ \\
\hline \multirow[t]{2}{*}{ Upper regime } & $0.10(0.07)$ & $0.05(-0.02)$ & $0.07(0.02)$ & $-0.02(0.05)$ \\
\hline & \multicolumn{2}{|c|}{4 quarters } & \multicolumn{2}{|c|}{6 quarters } \\
\hline Czech Republic & $\begin{array}{c}\text { before } 2007 \\
\text { (after 2007) } \\
\text { spending shock }\end{array}$ & $\begin{array}{l}\text { before 2007 } \\
\text { (after 2007) } \\
\text { revenue shock }\end{array}$ & $\begin{array}{c}\text { before } 2007 \\
\text { (after 2007) } \\
\text { spending shock }\end{array}$ & $\begin{array}{c}\text { before } 2007 \\
\text { (after 2007) } \\
\text { revenue shock }\end{array}$ \\
\hline Lower regime & $0.37(0.24)$ & $0.10(0.03)$ & $0.35(0.18)$ & $0.09(0.02)$ \\
\hline Upper regime & $-0.28(-0.43)$ & $-0.15(-0.19)$ & $-0.21(-0.27)$ & $-0.10(-0.14)$ \\
\hline
\end{tabular}




\section{Abstract}

\section{EFFECTS OF FISCAL POLICY SHOCKS IN CE3 COUNTRIES (TVAR APPROACH)}

\section{Rajmund Mirdala, Martin Kameník}

The real output deterioration, high fiscal deficits and increased sovereign debt burden represents key phenomena that affected the maneuverability of fiscal authorities in the early crisis years. Controversy between fiscal sustainability and fiscally driven economic recovery fueled a large number of academic and policy discussions about the appropriate response of governments to the crisis challenges. Empirical literature provides mixed evidence about the effects of fiscal policy adjustments on the macroeconomic performance. Moreover, pro-cyclical patterns in fiscal policies of many countries during the pre-crisis period did not reveal clear lessons learned that would be beneficial for fiscal authorities during the crisis years.

In the paper we examine effects of the fiscal policy shocks in CE3 (the Slovak Republic, the Czech Republic and Hungary) within different stages of the business cycle by employing threshold vector autoregression (TVAR) model. We calculate fiscal multipliers and generalized impulseresponse functions to assess the responsiveness of the real output to the fiscal policy adjustments. The main objective is to determine whether effects of the fiscal policy shocks differ during expansion and recession. Our results indicate that the size of fiscal multipliers and responsiveness of the real output are generally higher for spending fiscal shocks while effects of revenue fiscal shocks are much less dynamic in all three countries. While the effects of the fiscal spending shocks are more dynamic during recession in the Czech Republic and Hungary, fiscal spending multipliers in the Slovak Republic are generally high during the recession as well though higher during expansion. Moreover, differences in the responsiveness of the real output are slightly higher in case of the expenditure based fiscal adjustments in all three countries (in terms of both, regimes and subperiods).

Key Words: Fiscal policy, threshold VAR, structural shocks, fiscal multipliers, generalized impulse-response function.

JEL Classification: C32, E62, H60.

DOI: 10.15240/tul/001/2017-2-004 